


\title{
FISH INDUSTRY IN THE UNITED STATES
}

\section{HEARING}

BEFORE A

\section{JOINT SUBCOMIMITTEE OF COMIMERCE AND FISHERIES}

\section{UNITED STATES SENATE}

\author{
SIXTY-FIFTH CONGRESS \\ SECOND SESSION
}

TUESDAY, OCTOBER 1, 1918

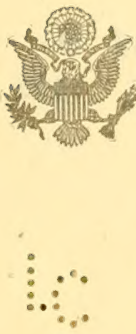

WASHINGTON

GOVERNMENT PRINTING OFFICE 1918 


\section{COMMITTEE ON COMMERCE.}

DUNCAN U. FLETCHER, of Florida, Chairman.

GEORGE E. CHAMBERLAIN, of Oregon. JOSEPH E. RANSDELL, of Louisiana. MORRIS SHEPPARD, of Texas. JAMES K! VARDAMAN, of Mississippi. JOHN K. SHIELDS, of Tennessee. THOMAS S. MARTIN, of Virginia. JOHN H. BANKHEAD, of Alabama. FURNIFOLD MCL. SIMMONS, of North Carolina. JAMES A. REED, of Missouri.

WILLIAM F. KIRBY, of Arkansas.
KNUTE NELSON, of Minnesota.

WILLIAM ALDEN SMITH, of Michigan. WELSEY L. JONES, of Washington. I.AWRENCE Y. SHERMAN, of Illinois. WARREN G. HARDING, of Ohio. BERT M. FERNALD, of Maine. WILLIAM M. CALDER, of New York. HIRAM W. JOHNSON, of California. IRVINE L. LENROOT, of Wisconsin.

COMMITTEE ON FISHERIES.

JOHN F. NUGENT, of Idaho, Chairman.

DUNCAN U. FLETCHER, of Florida. THOMAS S. MARTIN, of Virginia. JOSIAH O. WOLCOTT, of Delaware. WALTER GUION, of Louisiana.
TVESLEY L. JONES, of Washington. CHARLES CURTIS, of Kansas. BERT M. FERNALD, of Maine. DAVID BAIRD, of New Jersey.

\section{JOINT SUBCOMMITTEE.}

Mr. FLETCHER, of Commerce.

2
Mr. NUGENT, of Fisheries.

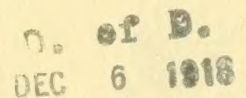




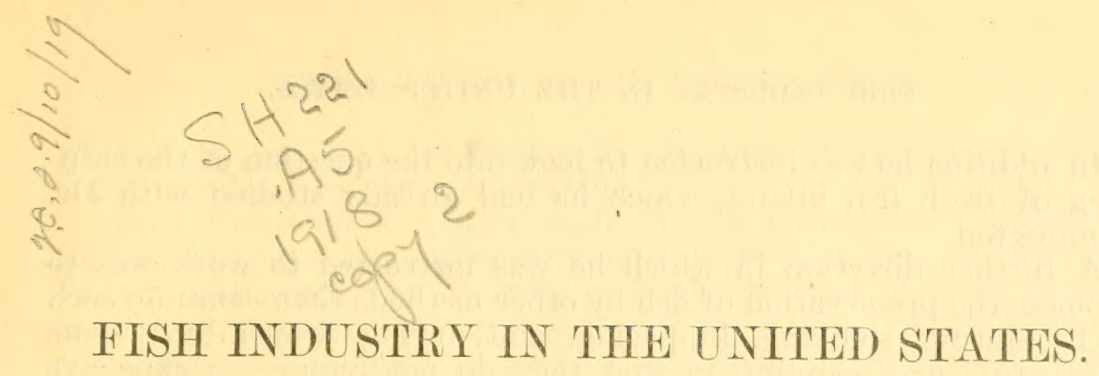

TUESDAY, OCTOBER 1, 1918.

\author{
United States Senate, \\ Subcommittees of the Commitee on \\ Commerce and Committee on Fisheries, \\ Washington, D. $C$.
}

The subcommittees of the Committee on Commerce and Committee on Fisheries met at 10 o'clock a. $m$. in the committee room of the Committee on Commerce, Capitol, in joint session, pursuant to call, Senator Duncan U. Fletcher presiding.

Present: Senators Fletcher (chairman) and Nugent.

Present also: Senator Robert L. Owen and Senator James D. Phelan; Dr. Carl L. Alsberg, Chief Bureau of Chemistry; Dr. E. D. Clark, assistant to Chief Bureau of Chemistry; Dr. F. W. Weber, chemist in charge of Animal Physiological Laboratory, Bureau of Chemistry; and Dr. M. E. Pennington, Chief Food Research Laboratory, Bureau of Chemistry, of the Department of Agriculture; Dr. R. E. Coker, assistant in charge of Division of Scientific Inquiry, Bureau of Fisheries, and Mr. L. Radcliffe, assistant in charge of Division of Statistics and Methods, Bureau of Fisheries, of the Department of Commerce.

The Chairman. Dr. Alsberg, will you kindly make a general statement for the purpose of the record?

\title{
STATEMENT OF DR. CARL L. ALSBERG, CHIEF OF BUREAU OF CHEMISTRY, DEPARTIENT OF AGRICULTURE.
}

Dr. Alsberg. The Bureau of Chemistry has had a small appropriation of some $\$ 14,000$ or $\$ 15,000$ for four or five years for the promotion of the utilization of fishes for food and other uses. When the present war emergency arose it seemed wise to spend a part of that appropriation in stimulating the production of fish in various seaboard States, among others in California. For that purpose Dr. E. D. Clark, who had been under Dr. Pennington in charge of the fish-handling work which was done in the Southeast and Gulf waters, was sent to California in order to stimulate the production of fish for food purposes there. The work which he was instructed to undertake was along several lines. In the first place, he was instructed to investigate the best methods of canning and packing the various fish now being canned and packed in California-in the main sardines and various varieties of tuna-and in addition to endeavor to induce the California packers to can other varieties not now used to any appreciable extent for food, such as barracuda and anchovy and a considerable number of other varieties that are now but little used. 
In addition he was instructed to look into the question of the shipping of fresh fish inland, which he had already studied with Dr. Pennington.

A further direction in which he was instructed to work was to promote the preservation of fish by other methods than canning, such as by salting, smoking, kippering, and drying, which have some advantages over canning in that they do not require so extensive equipment, nor use tin plate, but have a disadvantage in that the product is not so completely imperishable as are canned foods.

These are the three directions along which he was instructed to operate: To improve methods of canning and to endeavor to stimulate the use of varieties not now utilized; to assist in whatever way possible in the transportation to market of fresh fish, especially varieties not now being utilized. I might mention shad, the roe of which is shipped and the fish itself is not eaten very much in the bay cities in the vicinity of San Francisco. My statement on that is right, is it not, Dr. Clark?

Dr. Clark. Yes.

Dr. Alsberg. And also to stimulate and investigate the salting and smoking and similar methods of curing and preserving fish. As I said, those are the three lines of work that he was supposed to undertake. Some of our bulletins, reports, and statements to the trade are submitted for the Senators' inspection.

Senator Fuetcher. Has the Bureau of Fisheries cooperated in that work, or has your investigation been independent of that?

Dr. Alsberg. No, Senator; there has been nothing done by the Bureau of Chemistry which has not been done with the cooperation and knowledge and approval of the Bureau of Fisheries. No work has been undertaken at any time by the Bureau of Chemistry without getting the approval of the Bureau of Fisheries before it was begun.

Are you interested in learning how the Bureau of Chemistry got into this work at all?

Senator Owen. I would like to know it.

Dr. Alsberg. Well, it is largely my fault, personally. A good many years ago, before I had any connection whatever with the Federal Government, except that of any other citizen, I was an instructor in chemistry in the medical faculty of Harvard, and in the summer the Bureau of Fisheries used to employ me for three months during my vacation to go down to Woods Hole, where they have a station, to make analyses of food fish. That was in the days when Mr. Oscar Straus was Secretary of Commerce and Mr. Bowers was Commissioner of Fisheries. At that time I suggested to Mr. Straus and Mr. Bowers, whom I happened to know personally very well, that in my judgment it would be a very wise thing for the Bureau of Fisheries to undertake a rather extensive piece of work to investigate and promote the industrial side, as you might call it, of the industries which are based on sea products, such as the proper methods of cold storing fish and handling fish, the manufacture of glue, the production of oil from fish and its utilization, the possibility of utilizing fish oil for food purposes, the manufacture of potash from kelp-all of that sort of thing - and the production of leather from various sharks and porpoises, and the use of fish which are not now being used. Both Secretary Straus and Commissioner Bowers approved of the general idea and said that they would take it up with Congress. Whether that 
was done or not I do not know. At any rate, no appropriation was made and the work was not started.

Then, when I became, about eight or nine vears later, Chief of the Bureau of Chemistry under Secretary Wilson, I went to Secretary Wilson and asked for his approval-the Bureau of Fisheries not having procured an appropriation-for the Bureau of Chemistry to ask Congress for money to make a beginning in this work. Secretary Wilson signed a memorandum to me, which I prepared for him, that he approved of the plan. I asked him to do that, because he was about to retire, there being a change in administration; and when the new administration came in I put this question to Mr. Houston, showed him Mr. Wilson's approval, and received Mr. Houston's consent to ask for a small appropriation from Congress, some $\$ 15,000$. We asked actually for $\$ 25,000$, but we got $\$ 15,000$. We have had that now for four years, is it not, Dr. Pennington?

Dr. Pennington. Just about four years.

Dr. Alsberg. That appropriation was very small to carry on the many kinds of work, and it seemed wiser to put almost all our eggs into one basket in the beginning than to fritter a small appropriation away in many lines of work.

The particular part of the fish industry which seemed to require help was the question of properly marketing fish. The waste which occurs in sending fresh fish from the coast inland is terrific. They are handled badly; nobody has ever made a study of the right way to ship them, how to freeze them, how to chill them, and all that sort of thing. It happened we had made just that kind of study for poultry and egos, which, like fish, are very perishable. So the first piece of work we undertook was the improving of the methods of transporting fresh fish, in order that the consumer should get fresh fish and at a reasonable price, and so that we would overcome some of the prejudice against fish as they exist.

When I say "fresh fish," I am including the frozen fish, and using that term as opposed to canned or salted or smoked or kippered fish, because a properly frozen fish is a perfectly satisfactory article, a perfectly satisfactory food. The trouble with frozen fish has not been, and the prejudice against them is not due, to the fact that freezing is an unsatisfactory way of preserving them, but it is due to the fact that a good deal of freezing has been done by people who do not understand how to do it, because the way to do it is immediately to chill the fish away below the freezing point and to dip him in fresh water. The fish, being much colder than the water, instantly covers itself with a hermetic seal of ice, and then it is put in storage and it is sealed as perfectly, as long as it is kept cold enough to keep ice on it, as though it were canned by some housewife in a Mason jar with a rubber seal. If the fish is not consumed within two or three months, then the seal has to be renewed and the fish has to be redipped, because ice evaporates without melting, which is not generally realized. It is what the physicists call subliming: That is the main point about freezing fish. But there are a lot of tricks about how to handle them and keep them fit from the time they are caught to the time they are frozen: and that is the trouble.

So the bulk of the money which we had was spent on improving the quality of the fish and teaching people around the country who were handling fish how to get them in right shape for the market. 
Bulletins have been issued giving directions for the proper methods of freezing fish, handling shrimp in the South, and also bulletins on the food value of fish.

A smaller sum of money was spent on helping to improve the pack of sardines on the Maine coast.

Among the localities in which we have endeavored particularly to promote this handling of fresh fish has been the Carolinas and Florida. On the Gulf coast of Florida, or at any rate in Florida, there are many varieties of fish which never come into the market, because nobody has made a serious effort to market them; and in the Carolinas the transportation conditions - concerning which Dr. Pennington, if you wish details, can give you more information than I can-are such that a large percentage of the fish before they reach the northern markets have to be thrown away- go to the dump-because the transportation conditions are not right. That also is the condition in Florida. It was necessary to organize the transportation in cooporation with the railroads. It was necessary to get the railroads to put on proper refrigeration service, and it was necessary to study what that service must be-how the fish should be iced.

When the food-production bill came, I asked the Secretary of Agriculture to allot to us some money with which we could expand and make more effective the work which we were then doing, and it is with some of that money that Dr. Clark was sent out to California. It is with that money that Dr. Pennington undertook a service which may be interesting, if you care to listen about it, to popularize and put upon the market fish from the west coast of Florida in such cities as Indianapolis, Louisville, and Nashville.

Before that work was undertaken it was taken up with the Bureau of Fisheries. In Florida the Bureau of Fisheries had Mr. Douthart cooperating with Dr. Pennington and Mr. Hill, of the Bureau of Chemistry, and in California Dr. Clark was continuously cooperating with such of the Bureau of Fisheries people as happened to visit that district.

I may add that before we got the original small appropriation, four years ago, I went to Dr. Smith, who had just recently been made Commissioner of Fisheries, and asked him whether it was agreeable to him for us to go into this work. He said that inasmuch as they had not succeeded in developing the work, that it ought to be done by somebody, and if we could get the appropriation to do it he would not object; and we have had a sort of direct understanding between us that whenever the Bureau of Fisheries was in a position to carry on this work on a more extensive scale or to better advantage than we could carry it on, we would readjust it, and the Bureau of Chemistry would, if it seemed wise, gradually draw out of it.

Senator Owen. So Dr. Clark then made this particular inquiry on the California coast, and he has now the samples of those different packs and fish products that are used there?

Dr. Alsberg. Might I say, Senator, that we have put up a good many experimental packs of new products ourselves? But we did not have many of them available in the Bureau of Chemistry, and there was not time to telegraph to California and get them by express. So Dr. Clark-

Senator Owen. That could be added and put in with this matter by an addenda. 
Dr. Arsberg. Oh, Dr. Clark is in position to discuss it, but he is not in a position to show it; that is all.

Senator Fletcher. We will now, if you please, hear Dr. Clark.

\section{STATEMENT OF DR. E. D. CLARK, ASSISTANT TO CHIEF OF BUREAU OF CHEMISTRY, DEPARTMENT OF ARICULTURE.}

Dr. Clark. My chief, Dr. Alsberg, has spoken my speech for me, hecause he has outlined in a concise way everything we did.

One of the main troubles we found when we went to California over a year ago-and I may say that we went there at the request of Mr. Ralph P. Merritt, the able food administrator of Californiathat some reform was necessary in the methods of packing fish in southern California. I do not need to describe that in detail, because Dr. Alsberg has outlined the situation in Maine, and it existed in California to some extent. The packers realized this and had a large mass meeting at the Athletic Club in Los Angeles. Mr. Merritt addressed them, and after the meeting was over they asked us what we thought should be done. We told them that the quality of the pack as well as sanitary conditions in the canneries would have to be improved, and they immediately asked me to draw up a series of rules and regulations for the standardization and improvement of the quality of the pack. We did that, and at another meeting a little later-

Senator Owen. Will you put those rules and regulations into the record?

Dr. ClarK. I have them right here. I can give them to the stenographer later.

(The rules and regulations referred to were subsequently furnished by Dr. Clark, and are here printed in full, as follows:)

Proposed rules for the inspection and standardization of sardine canneries.

CATCHING.

1. Keep fish in boxes not over 8 inches deep or in wells with water.

2. The custom of walking on fish should be forbidden.

3. Keep fish always wet and away from direct sunlight.

4. Fish boxes and other storage places to be washed after every load.

RECEIVING.

1. All belly-blown and soft fish should be refused at the dock.

2. Avoid all handling or rough treatment that may result in bruising the fish.

3. Store in containers not more than 8 inches deep.

4. All boxes, tools, conveyers coming in contact with the fish should be washed daily.

CLEANING.

1. Removal of entrails to be complete in all cases.

2. Fish to be thoroughly washed after cleaning.

3. All boxes, benches, and woodwork to be washed thoroughly at least once daily.

4. All knives, tools, and metal utensils to be sterilized and steamed at least once daily.

DRYING AND COOKING.

1. Drying and cooking to be carried out in a uniform way as to temperature and time, depending upon the method used in each individual plant. 
PACKING.

1. All fish to be on flaking trays or packed and processed within five hours of the time received from the fishermen.

2. Fish to be packed in a uniform way, depending on the size of the can and the style of the pack; only fish of given size and number to be placed in each can.

3. Sauces and oils used are to be of uniform high quality and of the grade commonly used for food purposes.

4. The pack should be full net weight, or slightly over.

PROCESSING.

1. Time, temperature, and style of process to be uniform in each plant, depending on the general method used there.

LABELING.

1. A label should not be misleading in any way and should conform in every way with State and Federal laws.

2. Goods packed and inspected as herein stated may bear on the label the following legend: "Packed and inspected in accordance with the official standards of the Southern California Packers' Association."

BOXING,

1. Cases of goods packed and inspected according to these rules shall bear a stamp giving the inspector's number and the date, to aid in placing responsibility in case of complaints received later on.

DUTIES OF INSPECTORS.

1. To pass on the quality of fish received from the fishermen.

2. To see that all the above regulations concerning the catching, receiving, cleaning, cooking, packing, and labeling of fish are carried out in every particular, especially regarding cleanliness and standard pack.

3. To see that the general sanitary regulations are strictly adhered to in all cases.

GENERAL SANITARY REGULATIONS.

1. Whitewash should be used frequently on walls and ceilings of workrooms and canneries.

2. Screens should be installed to exclude flies in rooms where raw or cooked fish are exposed.

3. Workrooms should be as light as possible. This is in the interests of efficiency and careful grading, as well as sanitation.

4. Wash rooms and toilets should be kept scrupulously clean and due provisions made for maintenance of strict personal cleanliness on the part of all employees.

5. All metal knives, tools, trays, and baskets should be sterilized with steam at least once in 24 hours.

6. The floors should be of concrete, if possible, and frequently flushed with rumning water.

7. Worktables should be kept clean, as free from litter as possible, and thoroughly washed with lye or antiseptic solution daily.

8 . Forewomen should see that the hands of those who handle fish are thoroughly washed after each absence from the room.

9. Caps to cover the hair, and a clean apron should be worn by women employees handling fish.

10. Forewomen should observe carefully the general health of women under them and also watch especially for any signs of skin or local disease.

Dr. Clark. We outlined the rules and regulations that seemed to us would make the desired improvement, both with a view to improving the sanitary quality and standardizing the pack. Of course, it is obvious in any packing organization that the standardization of the different operations must be as nearly complete as possible, not 


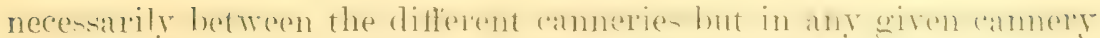
they must pack their fish as far as possible and handle them in exactly the same way. If they do not you will always notice great differences in the quality of the product.

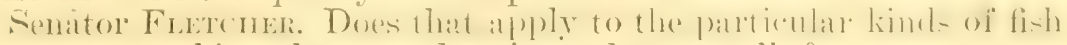
they wele packing there, or does it apply generally?

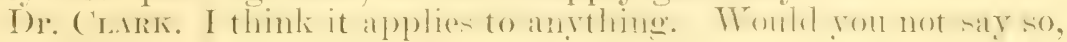
Dr. TVeber?

Dr. WEerer. All the different kinds of fish.

Dr. Cr.srk. The Senatol wants to know if you do not think it is

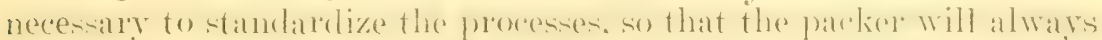
do about the same thing with any particular kind of fish.

Dr. WEerer. They all ought to be handled the same way. That is

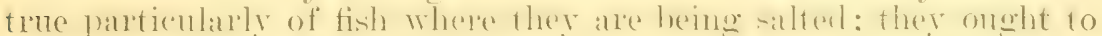
have the same degree of salting.

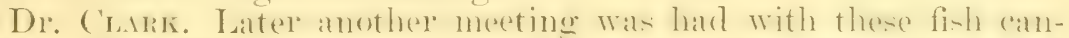

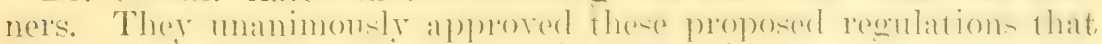
we had dramn up, and the next thing they did was to install an in-

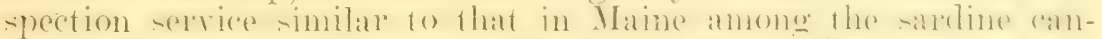
ners. At that time there were abont 22 canneries in sonthern California packing sardines. This applied only to sardines. by the way.

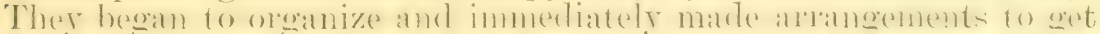

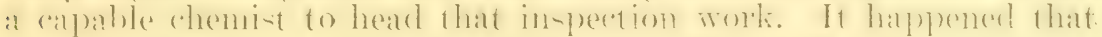
they chose one of our chemists from the Bureau of Chemistry, and since then he has been carrying on that work.

Senator Owex. Tho is in charge of that work?

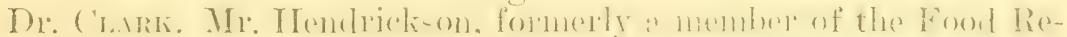
search Laboratory and a member of the Bureau of Chemistry for 10 or 11 years. He has met with considerable success, and it is a source of great satisfaction to us that the final rules and regulations that have been adopted by the inspection service after experience with them are practically identical with the ones we tentatively drew up over a yeal ago.

This spring the packers of fish in California-who. by the way,

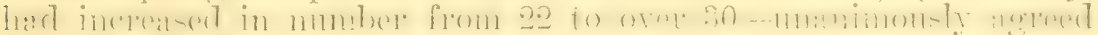
to put the packing of tuna under the same rules for standardization and improrement of quality as sardines. So. at the present time in southern California there are over 30 cammeries banded together in a self-imposed inspection under the leadership of a man who has had a wreat deal of food-inspection experience and a nleat deal of chemical training. He also has a chemical laboratory to control the whole thing and 25 inspectors.

I am giving that to you in detril, becanse I think that it is one of

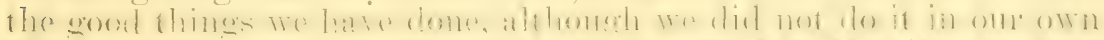

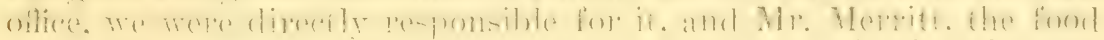
administrator. and other's familiar with the California situation say it has been a life-sarer for the industry.

Senator OwEx. As I understand it, the difliculty about packing

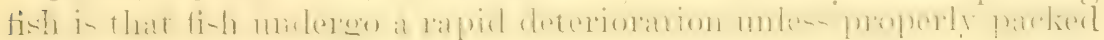
and properly handled.

Dr. Clari. And rery promptly.

Senator Owex. And otherrise ptomaines are liable to develop in the food itself? 
Dr. Clark. That is it exactly.

Senator Owex. And results, therefore. in danger to human health if the packing is not done miformly under a fixed systen which will safeguard the product against ptomaine poisoning?

Dr. Chark. Of cour e, when you say "ptomaine," a chemist always wonders exactly what you mean.

Fenator Owex. We will let that pass. It means poisoning the public.

Dr. Cunri. It means disturbanee of rligestion more or less serere.

Since that time we have been continuing our work, as I might say. along the technical line; that is, we have had one chemist spending all of his times in the sardine canneries and tuna ramneries of sonthem California helping them in the actual troubles they meet. We have insuflicient funds for the necessary experinental cannery and laboratory.

Senator Owex. Are they salted, or are they packed in oils, or how are they packed?

Dr. Cinnz. They are not packed the same way they are in Maine. The sardine industry in California is an entirely different proposition. 'The fish are not caught in weirs. because the coast on the western part of this country sheers off into deep water. There are no flats and no places to jut weirs. and the only way one can get sardines is to go out with nets. The Japanese and "Italians are especially eflicient and go ont just before daylight, and by the phosphorescent weam in the water can encircle a school of sardines and bring then in. Sonnetimes they aet sn many they can not land them in the boat. From the time the fish are caright unt il they are actually packed in the cans there are a great many differences in the way that the fish are handled.

Senator Orwax. There must he a limited amount of time between the catching of the fish and the packing?

Dr. Cunis. There is a limited time between the catching of the fish and the packing. One of the original rules was that not more than five hours hould elape between the time the fish were calloht and when they were procesed. Howerer, that was not found practicable. and they had to extend the time to seren hours. We also had to malie rites and reculations regarding the elepth of fish in the boats.

Senator Owen. To prevent crushing?

Dr. Charix. Yes. In Maine, as I understand, there were more canneries than fish. The opposite is true in California. In California it is often perfectly feasible to go out a fer miles and catch more fish than the boats can bring in; and the fishermen natmrally want to bring all the fish they can, and they were in the habit of filling the boat 2 or 3 feet dieep, and the Italians and Japanese ralked all orer them with hip boots. So one of the regulations was to make the limit of the height of fish not to exceed 8 inches, but that was found too stringent and it had to be extended to 10 inches. I have noticed the Japanese and Italians paint a white line around the inside of the boat at 10 inches, and that is the dead line. Mr. Hendrickson's inspectors- who, by the way, are also deputies of the Fond dumintration-incist that the fish should not he loaded above that white mark. That, of course, is to prevent the weight of the

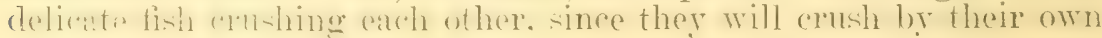


weight, and the botton fir.h will have their bellies broken theough. and when canned will look bad.

Dr. Alsbers. Iou might explain to the fereator. I)r. ('lark. how recently the saldine industry began and how really it was a side issue in California.

Dr. Cusn. It is a most interesting derelopment. Ibont two reals ano the tuma industry eame to its high point. In other words. the beginning of the tura industry itself does not wo much latek of 1911 or 1912. and at great expense. eren at the expense of selling fish below cost, the people who were interested in tuna sold a can of tuna at 10 cents when it cost 20 cents to put it up. They had to do that to meet the (ompreticiom with silmon. which is a staple article. 'Tuna is now e-tablished and u-nally sells for a little higher price than salmon.

Over 8.000 .000 cases of salmon, each of 48 cans, were packed in the United States and Alaska in 1917; also about 150,000 cases of sea and river herring and 400,000 cases of tuna; brobably 10,000 cases of mackerel and 2,000,000 cases of sarlines in Maine. while about 1.500,000 cases of sarlines were canner in Californial. Small palcks of desirable but insufliciently introduced fish like rellowtail, bonita, etc., were also male. It is likely that the fish canners of the United States receired about $\$ 65,000,000$ in 1917 for their product.

The Bureau of Chemistry has recently investisated the packing of river herring on Chesapeake Bay. There are approximately 60 establishments of this sort packing sult river herring. camned river helring, and canned roe. It is estimater that 40,000 barrels of salt fish. 54,000 cases of camned fish, and 44,500 cases of roe are packerl annually. This is estimated to require $37,000,000$ fishes.

In the field of the preselvation of fish by salting and drying, it may be said that about $\$ 6,000,000$ or $\$ 7,000,000$ morth of codfish and related fishes were preserved in this way at Gloncester. Mass. and stations in Mlaska. Alout 30 per cent of the amount of salt dried colfish prepared was exported principally to the West Indies, Sonth America, and Central America.

At present the importation of sardines and kippered herring is practically negligible, owing to the disorganized condition of the producers in Europe, embargoes, and the shipping situation in general. However, in 1913, the year before the war, the United States imported something orer $\$,, 500,000$ worth of sardines and anchories in oil and over $\$ 3.000,000$ worth of pickled and canned herring together with over $\$ 1.000 .000$ worth of salt mackerel.

It is very difficult to secure statistics of the total value of fish produced in any countrr. The latest accurate figures for the United States are those of the census made in 1908. Howerer, it is possible to secure accurate figures in the case of Alaskin for 1917 and conservative estimates have been marle for the United States in 1917 and other countries from the latest available figures and the totals are shown in the table below. The value to the producer is the one given here. In the United States the retail values would be from 50 to 100 per cent greater than these figures.

Estimated value of fish produced in the United States and forcign countries.

\begin{tabular}{|c|c|c|}
\hline Country. & Year. & Value. \\
\hline 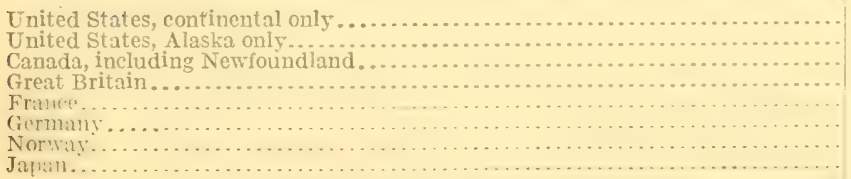 & $\begin{array}{l}1917 \\
1917 \\
1916 \\
1916 \\
1913 \\
1913 \\
1913 \\
1911\end{array}$ & $\begin{array}{l}\$ 60,000,000 \\
51,000,000 \\
45,000,000 \\
54,000,000 \\
33,000,000 \\
11,000,000 \\
14,500,000 \\
63,000,000\end{array}$ \\
\hline
\end{tabular}

Tuna can only be ("anght about thee or four months in the simmer, and at best it is a highly uncertain undertaking. 


\section{Senator Owen. Are they caught with nets?}

Dr. CLark. They are caught with hook and line mostly and it is only at certain times they (an catch them. They have to be (aught one at a time. Often the fishermen go out for many days and do not see any tuma, and the next time they will find so nany tuna that all they have to do is just put out hooks and lines and just drag them in.

Senator Owen. How large are they?

1). Cr.nik. They vary greatly in size, depending on their age and specics. Of course, when I sily " tuna," I mean there are three different fishes packed as tuma, all closely related.

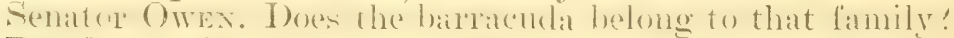

Dr. Clark. No; that is a different type of fish. There is a fish on the Athatice known as "tumy " fish, which is nearly iclentical. or" at any rate very closely related to the tuma in California.

Senator Owex. What is the difference?

Dr. Crark. Albacore is the name of one; and then the real or leaping tunis. and another. I think they all the yellow-lin tuna. Persomally, I can not pick wut all of those different spereses. but the fishermen can readily tell the difference. All are accepted and paid for at the same rate.

Senator Owen. Are they packed in salt?

Dr. Clark. They are packed in cottonseed oil in a different way from saldines. It is an entirely ditlerent indu-trv. hut owing to the uncertainty of the catch, the people who carry it on renlized they wonld have to look to other fields, firstly, in order to keep going contimuously and keep their organization of labor together; and,

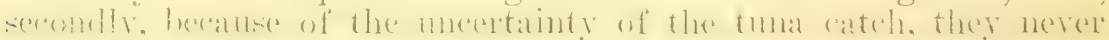
knew whether the next year they wonld have any fish or not. In that haphazard condition of tuna packing, they began trying to pack sarerlines.

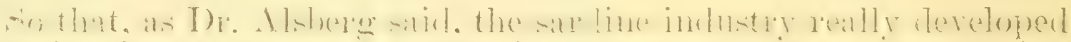

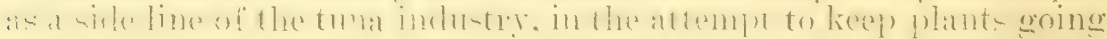
all through the year. In California sardines can be caught about 10

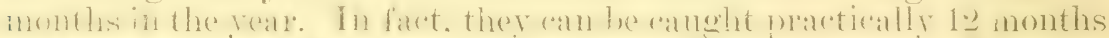

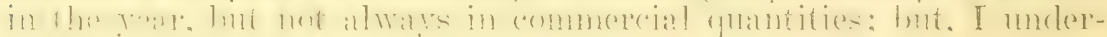
stand, in Maine that in certain months of the Tinter they can not operate. Probably in Maine the season is from April to Kovember.

Senator Fretcirre. Is tuma found anywhere else except on the California coast?

Dr. Chark. They are found in the Hawaiian Islands and also in Japan and off Tower California.

Senator Owran. Are the sardines found off the Florida coast?

Dr. Cumrk. I think not, but, perhaps, Dr. Coker will tell us.

Dr. Correr. They are not the same sardines. There is nothing quite corresponding to the California sardine, which is the nearest thing to the European. There is one small sardine in the TVest Indian waters, but it does not come very much to FIorida.

Senatol Ower. Are they there in sufficient quantities to justify packing on the Florida coast?

Dr. Conms. I do not believe they are. There are times when they are fairly abundant, but are erratic in quantity.

Senator FL:TcuEr. Is menhaden related to the sardine?

Dr. Cokser. They belong to the same family of fishes, the herring family. 
Senator Owex. But the menhaden is not packed for human consumption?

Dr. Clark. I think not; no; not in any quantity.

Dr. Alsberg. The menhaden are being eaten, to a small extent, by the foreign population in some of the large cities. There is not any reason why the menhaden should not be caten as human food, and it has been in some cities by people who do not object to the oil.

Dr. Clark. As I was saying, we are trying now in every way we can to assist the canners in technical ways, and by that I mean by improving the methods of their plants. We fuund we had to

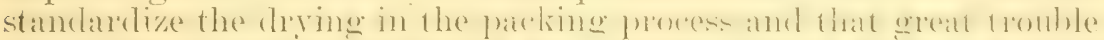

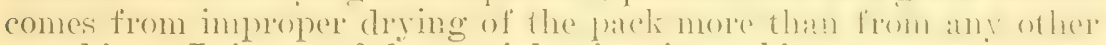
one thing. It is one of the crucial points in packing.

Senator Owen. How is that drying done?

Dr. Crank. That drying is done in various ways. Some people claim that to put up the hest samdines they shombl be dried in the sun on a wire screen before cooking, but you can readily understand that even in California it rains sometimes. So, during the winter season and usually in order to save time, they dry with mechanical dryers. The fish pass through on a long galvanized-wire screen belt that passes slowly back and forth in a heated compartment, where the temperature is kept at $90^{\circ}$ to $100^{\circ}$, and the warm air circulated by fans. The fish go into the dryer wet and come out dry, and this drying process is all automatic and continuous.

Senator Owen. Do they use the vacum process for drying purposes?

Dr. Crark. One cannery uses something which they call a racuum process. The main thing is to have the fish properly dried. If the fish are not properly dried when they go into the i, wit. oil the results are not satisfactory. They are usually fried in cottonseed oil. All those except the ones packed in round cans are fried, with a few exceptions. TVe feel a sardine that is steamed, at least under the Californial conditions. is not quite up to the stambind we would like.

Senator Owen. I was under the impression that olive oil was used in canning sardines.

Dr. Clark. It is in the packing. The frying is merely a cooking process, just the same as you would fry them in your home.

Senator Owen. Then they are packed in olive oil?

Dr. Alsberag. It might be added that the European-Spanish, Portuguese, and French-method is to fry in peanut oil, and then let the oil train ofl, and then put the fried firh into the "an and fill with olive oil.

Senator Owen. They are not cooked in olive oil?

Dr. Alsberg. No; because the cooking ruins the flaror, and you might just as well cook in a cheaper oil, such as peanut oil.

Senator FLETCHer. Is that so-called olive oil refined oil from cotton seed?

Dr. Clark. No. It has been misbranded, but not lately.

Dr. Alsiberg. I would not put it that way. We prosecuted about T.5 people moler the food and drugs aret. mostly Italians. small men aromed New Tork. New Haren, and Boston. for doing that.

Senator Owen. For packing in cottonseed oil?

Dr. Alsberag. To: for adulterating olive oil with entenseed oil. We can now say, without much danger of heing wrong. that when 
an article is branded olive oil in this country it is genuine olive oil, although every once in a while some little manufacturer will endearno to put something orer by labeling cottonseed oil as olive oil, and every year we have a certain number of prosecutions.

Senator Owen. Does the flaror of the fish keep as well when packed in cottonseed oil?

Dr. Clark. The question of using cottonseed oil or olive oil for packing fish is a question of taste rather than of anything else. By some sort of a peculiarity of nature it seems as though tuma which is patcker in cottonseed oil rloes not taste bad, possibly because the fish oil has been cooked out. But when sardines, under certain conditions. especially if not properly handled in the plant, are packed in cottonseed oil they do not have a flaror that is pleasant to many people. But I do not wish to take the position that cottonseed oil is not the proper thing to pack sardines in. It seems to me that the Maine industry. Which uses largely cottonseed oil, is on a rery aood foundation. They are putting out an article for which there is great demand and which has as high food ralue as the California sardines. In other words, people who in the past would buy foreign sardines, and pay or or 30 cents for a quarter-pound (an. packexl in olive oil. prefer to buy the California sardines and pay the price. In other words. there are two distinct markets for olive-oil and cottonseed-oil sardines.

Dr. Arsmerg. In time past a great quantity of the sardines packed in Maine were sold at retail for $\breve{s}$ cents a can. That is true, is it not, Dr. Weber?

Dr. WeBEr. Yes.

Dr. Arsmerr. They sold at if c'nts a can. They had to be packed in cottonseed oil to be sold at that price, and so far as actual food value is concerned there is not anything that mould give more food value for :) cents than such a can of sardines. Of course, they are not selling for that now. Five cents for a quarter pound of food consisting of nitrogenous material packerl in oil is certainly very cheap.

Senator Frevcuer. It looks as if the can wonld be worth that much.

Dr. Cr.ins. They are almost, under the present conditions.

Senator Owex. Are any of those fish absolutely dried out into a dry powder and used in that way?

Dr. Crurk. No. Dr. Alsberg called me back to Washington about a month ago, and just before I left California one of the firms that has hand the greatest success in producing dried vegetables started experiments on the dehydration of fish by the same process.

Senator Owen. By the true-vacuum process?

Dr. Cr.ark. I think so. but I have nerer had an opportunity to go to Santa Rosa. where their plant is, to examine it.

Senator Owex. Have you any samples of absolutely dried fish with you here to-day?

Dr. Cuark. I have not; it is all an experiment so far.

I believe, howerer, that Dr. Weber has done something along that line on the Atlantic coast with the fish caught there. And I think there is a future along that line. I was going to say, however, in passing. that at the present time we are trying to extend this work 
(mil packing sildines so as to pack mackerel in the simme way as tuma, and al:o kipjack. bonita and yollowtail. and a whole grompol ot hel fish of the very highest food ralue. which are not at precent utilized in any way.

Senator Owex. Are those fish abundant in California?

Di. Cutrk. They are very abundant in California, and as they are of different species they run at difterent times. on that a plant.

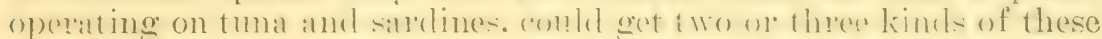

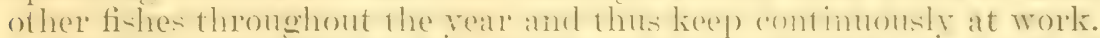

But the gevent diticulty is to get the people to "at these new kinds of fish. For instance. I will show your some very attractive cans of

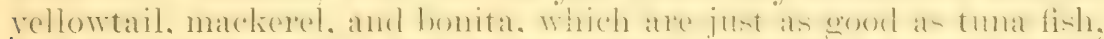

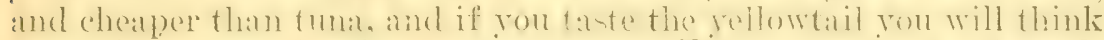
it has just as good a flaror as any tuna. But you can not sell much of it for it is clifficult to educate the people to eat it.

Senator Owex. They do not like the yellow name of the fish?

Dr. Clanr. 'They do not like the yellowtail name on the label. If we change to "amber fish," there is the same difficulty. In the

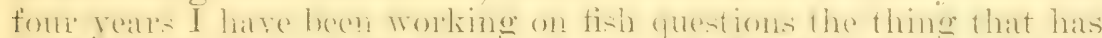

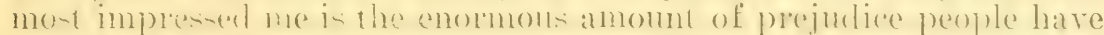
against fish. Many people will not eat it at all; others will eat it only once a week, and it is a pretty hard proposition to get people to eat a new fish or fish product any time.

sonator ( )wr.x. Did not the department name one fish the dogfish?

Dr. Crark. The Bureau of Fisheries christened some of these fish. with new names.

Senator Owex. Would it not be adrisable to give them a balutimal name that is more attractive than "dogfish"?

Dr. Cuark. Yes; but regard must be had to the pure-food law in that respect.

Dr. Alsberg. In the long run, Senator Owen, it pays better to lie(e) the names, to a certain extent, straight. Nom, talie. the sardine industry. Five or six vears ago, when canners were thinking of going into the industry to fill in between the tuna pack, they wanted to be permitted. under the food and drugs act, to pack roal wardines under the name of herring, hut we objected to that. Of course, we felt that real sarclines are a much better fish than herring, and that it would be bad policy to allow them to he called herring. I lo not doubt that to-day they are very glad that they packed them as sardines and not as herring, as they had originally intended.

In the same way, at the present time they have immense quantities of anchories on the coast which they are not nsing at all. That is one of the fish that they wanted to pack as sardines. The anchory is a fish which, in the markets of the East and of Europe, has a higher value than the sardine; and I am sure it would be better policr for them to go, perhaps, a little slower and pack them for a year or two as anchovies and to put them out on their merits.

In the case of the dogfish and the yellow tail, for which little market exists at present under those names, it is an entirely difierent question, as anchories have an actual marliet at present in certain districts.

The Bureau of Fisheries renamed the dogfish, with our consent, the "grayfish." 
Senator Fuetcher. Has not the tilefish come back into use?

Mr. RADChiffe. Yes, sir.

Senator Fletcher. How are they holding out?

Mr. Radclifee. Very well.

Senator Fletcher. Are they canning those fish at all now?

Mr. RadclifFe. No; they are all sold fresh.

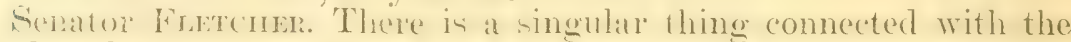
catfish that they get out of the Florida rivers; they are regarded there as having no food value at all. But when they ship it up to

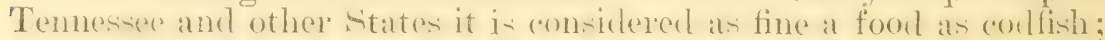
they consider it as very choice food.

Dr. ClarK. The same condition exists in Cảliformia in regard to shad and striped las.s. which were planted in Californial rivers: they are not native to California. The people of California do not eat the flesh of the shad, except in very limited quantities. The roe is canned and it is also shipped fresh, and is eaten fried with bacon; it is considered one of the ereat delicacies in sinn Francisco during the reason. But they have found out in Californial during the last few years that there (an ship this sharl east-from the sacramento River to the casterie cities-and malke a good profit out of it a fter pay-

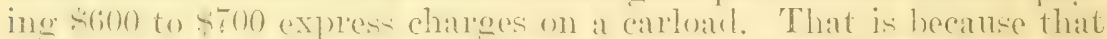
shad is not apprectated in the state where it grows. The undereloped

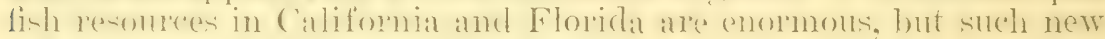
fish must be introduced to the people.

Senator Owen. So that the market for fish seems to be somewhat Thimsical, does it?

Dr. Clarr. Yes; it is a matter of prejudice; the flaror of the fish har lithle to do with it. The (alifornian does not eat sharl. because his nother did nom arok it for him when he was young; hut he will eat the shad roe, and he thinks it is fine.

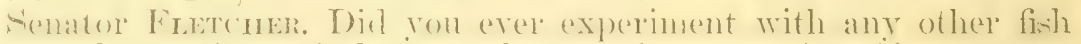
except the sardine and the tuna that you have mentioned?

Dr. Clark. Yes; I was going to discuss that in a few minutes.

Senator FleTCHER. All right.

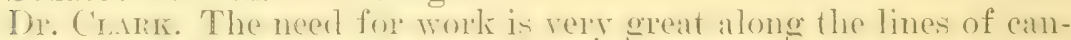
nine these diflerent new fish that I have mentioned, like vellowtail. bonitat skipjack, anchories, harracuda, rock eod, and sea hatse. Those fish are not utilized in canning in any quantity. There is great need of an experimental camnery to work out all these things in a practical way.

Fenator Owex. ('an they be canned in large packages, say of 15 or 20 pounds each?

Dr. ('insis. I roubt it. It is not possible to completely sterilize anythine in too large a can. The tonato camneries have found that when they tried to pack tomatoes in 1-gallon cans sometimes they mould spoil hefore they got into the hands of the consumer. It is not always possible to sterilize in large cans.

Senator Owex. On account of decomposition taking place?

Dr. Clark. Because the package is too large.

Dr. Arsmbra. In order to sterilize them you have to heat them 1hrough, and in trying to get the heat to penetrate all through in a large-sized can you burn the outside hefore you get the heat into the interior. so that you run the risk of not having the interior sterilized, and it will decompose. 
Dr. Cuarr. And that, of course, would be very much worse in the case of fish than with regetahles, becanse the decomposition product: are so very much more offensive. So that I doubt if it is feasible to pack fish in large cans.

senator Owex. So that the patching of fish must he dome in comparatively shallow cans?

Dr. Crans. Tes: until we have further knowledge on the subject. I should say, ollhand, that it is a pretty good gulesis to say that canlarger than 1 pound for fish could not be used successfully.

Senator. Owrx. But if the moisture could be absolutely extracted. so as to leave an aboolutely dry fish, it could he camned in a can of any size, could it not?

Dr. Crark. That is probably true. But we should not confuse dehydrating with camning. When you dohydrate fish you put it in such a state that the bacteria can not grow in it. Now, you are using the absence of water in the same waty in dried products that your ale using the heat in the other kind of preservation he camning. The preservation of fish hy drying is an entirely dillerent proces from the preservation of fish or other products by canning.

Senator Owr.x. I understand that. But I Was contwilering thimatter in connection with furnishing Europe with a rapid supply of foodsuffs from our packing industry: I thought that possibly the fish, which are arailable in such quantities in this country, might be packed on a large scale and supplied to the people of Furope. whe are now suffering for food.

Dr. Carak. Surely. But when you used the word "packing." you led me astray, becanse in the firhing industry the term "palcking" is very often nsed in a technieal rense, meaning eamning. I thonght you meant to use it in that way.

Senator Owra. Trell. I have no technical knowlertere of the inclustry: but I have been inpreserd with the lack of food supplies in Europe: and T thought that Ameriea might respond to that need he packing fish on a rerr large scale and furnishing fish to the European people alone with the other food supplies that we are compelled to send them anyway.

Dr. Clark. I think we could do it.

Fenator Owex. What would be the best method of preserving fish for the purpose of furnishing Europe with food?

Dr. Clark. For export?

Senator Orwen. Yes.

Dr. Ch.me. That would be a pretty diffieult quetion to answer. If methods of drying fi-h were workes out so that they would be perfeetly satisfactory. I shomld think. ofthand. that that would be the hest method. because they would take less space. and no tin would be required.

Senator Owex. In that case, they would not have to ship water?

Dr. Clark. No.

Senator Owex (continuing ). Which carries with it the possibility of decomposition?

Dr. Crank. Yes: and you would not have to we tinplate, which is a serious matter at this time.

Senator Owex. The fish might he packed in hoxes of cardhoard. or something of that sort, might it not? 
Dr. Clark. Yes; if it was sufficiently dried.

Senator Futcher. Is there any way of preserving it by the use of salt?

Dr. Clink. There is; yes.

Senator Fietcher. Salting them and shipping them in cases?

In. CLark. Tes. Of course, there are two large fish-drving indusrries in the United States at the present time. One is the salt-cod industry around Gloneester and the other is the salt-cod industry in Alaska. The have made several successful smoked and salted fish products in California lately.

Senator Ores. Those fish can be handled in barrels, can they not?

Dr. Clark. They can be handled in barrels or in any way you want to handle them. provirled the fish do not get damp, or if the temperature does not get too high.

Senator Phel 1 x. If it gets too high?

Dr. Crark. Yes.

Semator Owex. What would be the leet method of packing fish for European consumption?

Dr. Crank. I am not prepared to answer that question; but I -hould think dehydrated, if we can do it. would be the best allround method.

sonator Owr. IBut rour burean has not had a sufficient appropriation yet in justify you in carrying on experiments in the drying method?

Dr. (Intris. I)r. Weber has, possibly, in New England; but I did r.ot tackle that problem in (aliforiial. ()ur funds there were only -uflicient to begin our work nn canning and salting and smoking fish in a small way.

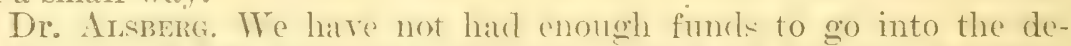
hydration of fish generally: we have gone more into the dehydration of vegetables.

Senator Owex. Well, in the dehydration of regetables. I understood you to say that you found a very great success?

Dr. Alsbers. Tes; it is a question at present largely of merchandizing; it is the same proposition with these new products of "putting it over." to to speak. with the public: that is the present difficulty.

Senator (mex. Does that dehydrating process also apply to fruit juices?

Dr. Alsbera. The have not worked ont a dehydrating process for ordinary fruit juices satisfactorily as yet. We are at work on it at present. but do not consirler that we have solved that problem.

Senator ()wex. My attention was called some time ago to the freezing process. by which the fruit juices would be subjected to a great leal of cold and frozen and then be rotated rapidly, as in a milk separator, so that the fruit juices would flow outside and leave the water as ice on the inside. and in that way the concentrated juice was a self-preserving fluid.

Dr. Alsmerg. Te have done that, but we have not regarded that as dehydration. Tou can take apple juice and remove about twothirds of the mater and get a reasonably thick sirup that will lieep for quite a long time, and that only has to be diluted to get back the original flavor; that is substantially the method you outlined. Fou can do that with most fruit juices, but we have not yet convinced 
anybody that there is enough moner in that particular proposition to have it taken up commercially. ire have demonstrated it and received most flattering opinions concerning the product, but no one has yet felt like risking an investment in it.

Senator Puelax. You spole of marketing dehrdraterl fruts and regetables. I understand that dehydrated regetables are a commercial success and are on the market now.

Dr. Alsiers. They are are on the market now, fenator, but I think it is a bit early to sa whether they are a commereial surecess or not.

Senator Prieldx. "The Government lias purchased from one man in California $\$ 1.200 .000$ worth of dehvelrated recetables. And he told me the last time I spoke to him that he had alrearly receired stio0.000 on account from the Government.

Dr. Alsberg. Yes.- I did not know the orders were as large as that. He has had Govermment orders. But, of course, that was not mhat I had in mind; that is an ephemeral matter: that is a thing that will end when we bring our people back from France.

Senator Prierax. But the Gorermment would not have made these purchases unless the products were satisfactory.

Dr. Ilsbeng. I do not mean to imply that the products were not satisfactory. They are satisfactory; but the arelage housewife at present is not buying them and the arelage restaurant lieeper or hotel keeper is not buying them.

Senator Owex. There is noboly really offering them in a definite way to the market, is there?

Dr. Ilsberg. No: that is also true at the present time. Nohody has undertaken the kind of campaign that has to be undertaken to market a lreakfast food; that remains to be done. The public does not know about them.

Senator Prelix. Well, a man like Horst, when the Government ceases to be a customer, will probably develop his trade elsewhere.

Dr. Alsberg. We hope so.

Senator Prieldn. I asked, on his behalf, that the commissary of the Army and of the Nary accept samples of his goods in various camps so as to try them, and they refused to do so, on the ground that they had no present intention of purchasing the products, and there was no use in sending samples; so that the purchases must have been made for use abroad and not in this country.

Dr. Alsberg. My understanding of the situation in this country. so far as the Quartermaster Department is concernerl, is as follows: The Quartermaster Department says this is no time for trying experiments, and that the Quartermaster. Department will endearor to feed the men, wherever they may be, in as nearly the same manner as the men are accustomed to in their own homes as possible.

Senator Pirelan. Now, we are appropriating money for the Quartermaster Department to carry on its operations. and there is an cnormous item for transportation alone. And they ship these things in cans-and tin is a very valuable mineral product at this time-and it seems to me that it is very well worth while trying this experiment. I should think the answer of the Quirtermaster Department should be rebuked.

Dr. Alsberg. That is for shipping abroad: and the attitude of the Quartermaster Department, as I understand it. is that that department will buy these materials in so far as the shipping situation 
makes it necesiry, and not a bit more. They have bought some of these materials for shipment abroad, because the Shipping Board told them they could not get the space to send ordinary canned goods.

Renator Priel.1N. But the A grieultural Department must have told them that these dehydrated regetables are a good food.

Dr. Alsberg. Oh, yes.

Senator PHeL.1x. 'Then, if they are good for the amps abroad they are good for the camps at home.

Dr. Alsberg. Unquestionably.

Senator Pineran. And I muderstand that their use would save the use of 1.50 cars in sending the same food ralue in the dried product that was sent of the canned product.

Senator Owex. I agree with Senator Phelan that the Quartermaster Department deserves a rebuke. They have no right to sit there and discegares the saving of freight in this country when the Agricultural Department has demonstrated that these materials are just as good as fresh regetables when you add water.

Senator Pintax. That is my molerstanding; they are a wholesome kind of food.

Senator FLeTcuer. I think there is no doult-in fact. I can produce authority for the statement. if needed-that a manufacturer in Canada put ip some of these dehrilrated regetable products at the time of the Boer. ITar, and he had some left over, and they are now being used.

Dr. Clark. Yes, I think that is a fact.

Dr. Alsberg. That is correct.

Senator Fuetrifer. They are perfectly good now. I have tasted some soul) made of dehyrliaterl vegetables. and you can not tell the difference from that made from fresh vegetables.

Dr. Alsierg. You can not in the case of a stew or a soup. When you are serving the regetalule as a regetalile, it may have a different flavor. Its food value will be the same. exeept in one respect. that some regetables after they are dried have lost their antiscorbutic properties.

Senator Phelan. What properties?

Dr. Alsmena. Inti-corbutic: the property of preventing scurry. Of course. under" modern conditions that is not a factor: we do not have -curry, excret in infants who are fed on eertain alonormal foods; we do not have the scurvy here nowadays, and I have not heard from any one who has been in France that there is any evidence of tanger from it there. But it is only fair to say that some regetables lose this particular property-or, at least. in part. Otherwise they havo exactly the food value of the fresh vegetables.

Senator Owex. What etlect has the embargo on olive oil had on the packing of fish?

Dr. Clark. Of course, I can only speak for California.

Senator Otwen. I am speaking of Califormia.

Dr. ('r.sir. It happened in Monterey that the packer'sere pretty well silpplied with olive oil at the time the embargo went into effect. That is for the reason that the Monterey factories are canning orals mo-tly, on that the amount of olive oil they liecp always on hand there would pack enough quater or half pound cans for them. In sonthern California the people were not in such good shape; they 
were quite disturbed when the embargo order came out. We wired

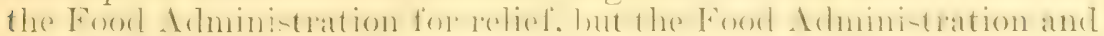
the War Trade Board said that the embareo would have to stick. As soon as we advised the packers of that, they knew they had to do something quickly: and in California there was a resource in the case of the peach-kernel oil; a great many peaches are dried and

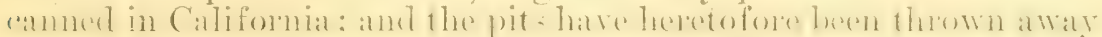
or used in the boiler's for fuel, at $\$ t$ a ton. 'They are now used for gas masks.

Dr. Alsbeng. They used to be cracked and sent to Germany before the war.

Senator Owex. Did they use the oil from the pench kelnel?

Dr. Clarr. Yes. By pressing the kernel they get a rery good oil.

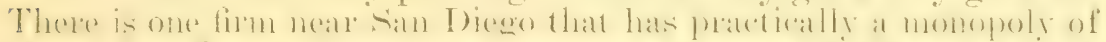

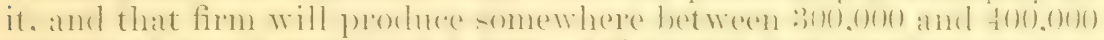

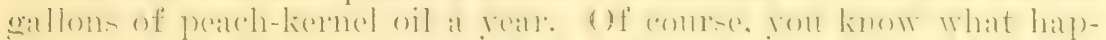

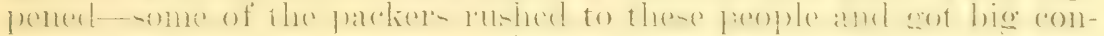
tracts, so that the others who did not get any early did not get any at all. So that some of them have had to fall back on peanut oil. We have had a good many different kinds of peanut oil.

Senator Owex. How does peanut oil serve the purpose?

Dr. Clarr. The peanut oil is rery good, but for people who like the real olive oil it has not the same flavor: there is nothing like the olive-oil flavor. That is because people have been acenstomed to it. They will pay any price for it.

Senator Owex. The olive oil, then, in preferred in the markets which have been established heretofore?

Dr. Clank. Yes; right in California, olive-oil sardines are preferred to a great extent.

Senator Pinelix. Why was olive oil put under embargo?

Dr. Chark. I think it was because of the shipping situation.

Senator Premax. The shipping situation?

Dr. Clatri. Yes.

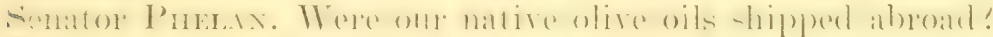

1)r. Chark. No: for some reason or other it was claimed, first-I

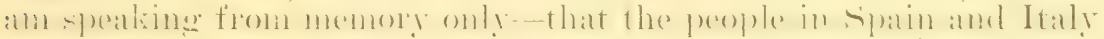
did not produce enough olive oil to export, they needed it at home;

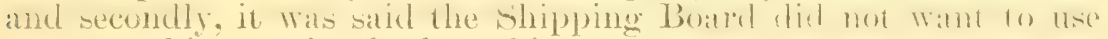
space on ships coming back to this country.

Senator Owex. I do not think that elaim is justified by the facts in either case, because the information I have in regard to the matter is that they have a surplus of olive oil in Spain; they are compelled to carry over a full year's extra supply, because they can not market it; and that there are Spanish ressels which would be released that

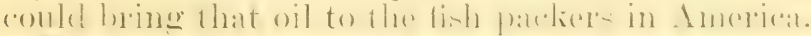

I). Cuan. That may be true. I have heard rmors to that effect

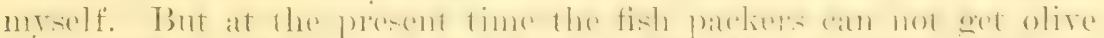
sil. and the only olive oil they hatre is what they happened to have in stock; and in some canneries I have seen large numbers of pint.

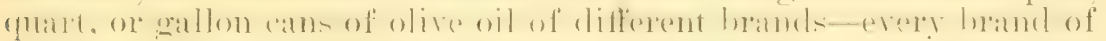
olive oil I ever heard of-being put in cans of sardines in order to fill their contracts for olive-oil sardines.

Senator Owex. Has olive oil increased rery much in price? 


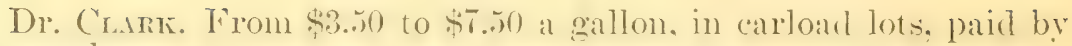
the packers.

Nenator P'nemax. How alout the olive oil produced in Califormia?

Dr. C'uari. The olive oil produced in Californial is a fine product for eating on at salarl. but it will not satisfy the reeuirements for packing fish, because there is too much acid in the oil: they are not careful enough in making it. By refining. this acis can be removed. but when it is most of the flavor is lost also. So the California canners do not use California olive oil.

Senator Prielax. I saw a statement yesterday that cottonseed oil is being substituted for olive oil.

Dr. Clark. For sardines?

Senator Phelax. No; for the table. And the Agriculture Department said that it was a frand under the pure food and drugs act. because it was labelerl and marketed as olive oil and it is not olive oil.

Senator Fletcher. Are the fish packers having any trouble by reason of having their men taken away from them?

Dr. Clark. Yes: that has been a rery verious situation in California.

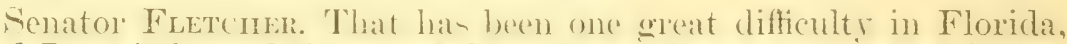
and I an informed that a good many perple engaged in the fishing and canning industry have been obliged to abandon it because they have lost their men.

Dr. Cunrk. That is a rery serions comslition. We have had a great many fishermen coming in io see if they conlel not get deferred classification in the draft.

Senator Phelan. How about conditions in Monterey?

Dr. Cunnx. There is not so much difliculty there. Most of the fishernen who go from san Franci-co to Dlatka are Americuns or naturalized Americans, ans many of them were talien from the salmon-packing operations in Alaska.

Another thing that I hould like to hise go into the reeord that

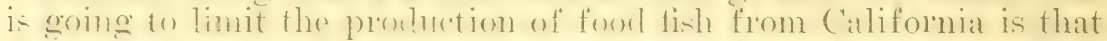
it is almo-t imposible to secure enough twine for making nets. Now. if there is any poscible influence that the Sonators can use with the imports bureau of the Trar Trade Tinard. or with the Tar Industries Boarl, to get twine through from the ()rient or from Scotland to California it shonlal be rone. hecanse without those nets the fishermen can wot eatch the firlh. At the present time they are using cotton net: which do not give satisfaction. They will hot stand up like the linen net:. Anel it is clained that the price of linen trine for making nets has risen in a most unreasonable manner. I am not gualifierl to say whethes that is true or not: but the fishermen are contimually ennplaining about the price they have to pay for linen twine for maling their nets. And that is a limiting factor, of course, in getting the fish.

Senator Phelan. How about Scotland?

Dr. CIAsti. A little comes from there. and little comes in from Japan now. As I saicl, a good deal of cotton is used; but cotton is not satisfactory. A good linen net will stand for tro or three years: a cotton net will not last one season. And certain of these nets are many hundred rarts long: and some of them cost several hundred dollars. 
Senator Fuetcrier. Can you use hemp from Manila?

Dr. Clark. They have tried to use hemp from Manila, but it is not altogether a suceess: in the water it frays out and goes to pieces, I believe.

Senator Owex. Do we pack our fish by the sane process as they do in Portugal and Spain?

Dr. Clark. I can not answer that question positively, but in California I think they do, especially where it is fried.

There are tro types of fish packing: One is called the round-can mexhod, which wats the first kind ueed: that con-ined in purking the fish raw and then steaning it: in other words. cooking the fish hy live steam and letting the water run out of the can. 'That was a. good idea in the beginning; but. as in the case of all of these other things, the people got careless: the fi-h were not proprerly cleaned: they wonld leare the entrail in : and it was owing to that cimplesenethat this system of inspection that I mentioned a while ago wastarted. But good romnd-can sardines are perfectly gool food and are being packed now in considerable quantities.

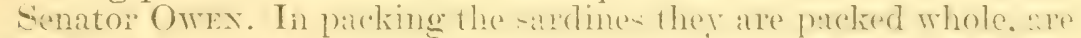
they not?

Dr. Clark. Minus their heads and entrails.

Senator Owex. They do clean them, do they?

D1. Crarm. They are supposed to, and under the inspection ther are required to do so. The fish are cut by hand. A person who can

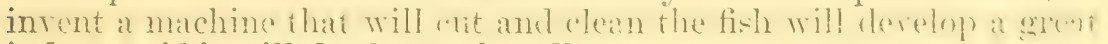
industry, if it will do the mork well.

Senator Pruman. Like the machine that takes the seed ont of the raisin grape? Could they use some such principle as that?

Dr. Clark. Tes; if they could develop that. They have a machine now in use in the salmon canneries that they call the "iron Chink." It is called Chink, becamse it talies the places of sureral (Chinamen. They used to have al gang of four or five ('hinament cloing the wort:

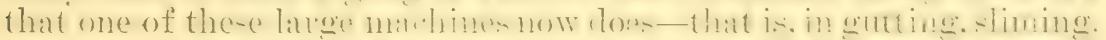
and handling the fish for caming: it makes all thate a medhateal operation. If we could do the rame thing in satrine camninge it w wely be a great improrement.

Dr. Arsberg. The bureau has been at work, under Dr. TVeber's direction. for several years on developing a machine for just that purpose. TVe have taken out several patents for one or another feature of it; the patents, of course, are taken out for the benefit of the general public. At present at Gloucester the Gorton Pew Co. are experimenting with that particular machine, under his direction. Whether or not it will be a suceess we do not know.

Senator Owex. Have you any dehydrated fish at all here that you can show us?

Dr. Alsibrg. TVe have some up in our laboratory, but I think none here. None of your dried-fish samples are here; are they, Dr. Weber! Dr. Weber. No: none of them are here.

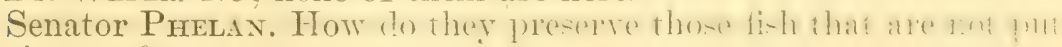
up in cans?

Dr. Arsberg. They are dried, salted, and smoked.

Senator Prielax. Sun dried?

Dr. Alsberc. No: usually dried and smoked. 
Senator Owew. The smoking acts as a preserrative, does it?

Dr. Alsibrg. The smoking acts as a preservative.

Senator OwEx. And it is preservative that is harmless and really. adds an agreeable flavor?

Dr. Alsberg. Yes; adds an agreeable flavor.

Senator Owex. The thing that I think is of urgent importance is to ascertain whether ol not we can add, in an immediate way, to the

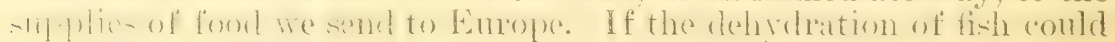
be worked ont by the department-the fish certainly are abundant enough-if they conld be dried and packed so as to be free from the possibility of fermentation.

Dr. Penningron. In some places and at some times, Senator; but

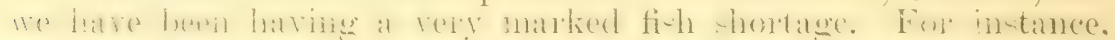

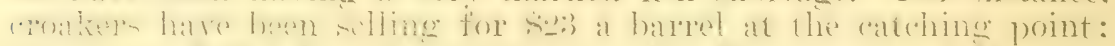

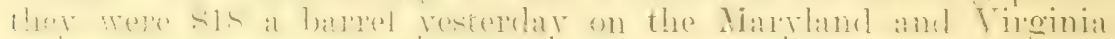
consts-200 pounds of fish sold for $\$ 18$ at the catching point. To try

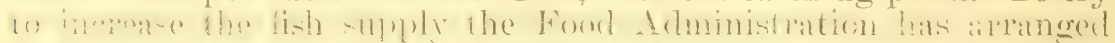
with the Emeroncy Fleet Board to build 75 fish trawlers, to be in operation this winter.

Senator Owex. Well, there are parts of the country in which fish

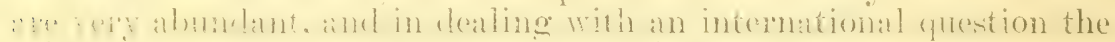
thing to do would be to go where the fish ave, and not to pay any attention to a place where they are not, because that is not of any interest.

Di: Pexningtox. If we could get the fish everywhere that they liappen to be- -..-

Senator Owex. Yes.

Dr. Pexningrox. Unfortunately, the fish do not happen to be always in one place; and we have these verv migratory fish to deal with-that we have to follow around, more or less-and we can not take either a drying factory or a canning plant along with us; and,

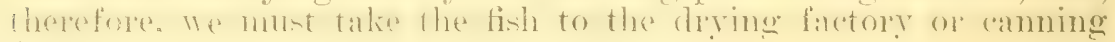
factory.

Dr. Alsberg. 'That is part of the problem; and another part of it

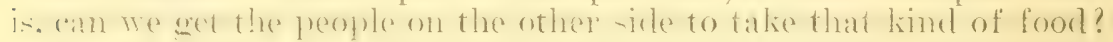

Senator Orex. I should think the people who were starving would take almost any kind of food, especially a food which has a high protein value.

Dr. Alsmerg. They ought to, but people are very peculiar about

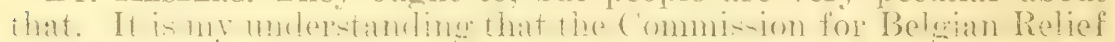

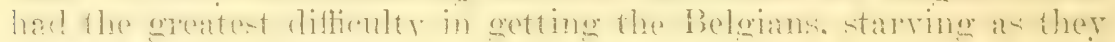
were, to eat corn meal: they had to give it a fancy name. As long

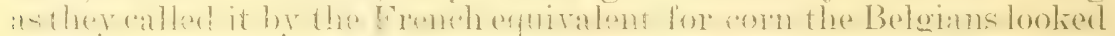
on it as cattle feed, and they could not be made to eat it. Then they called it Cerealine. or Cerealose, or something like that-camouflaged it-and they managed to get rid of it.

Senator Premax. There was a great campaign conducted once by a man named C. J. Murphy, under the Agricultural Department, to

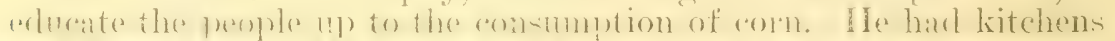

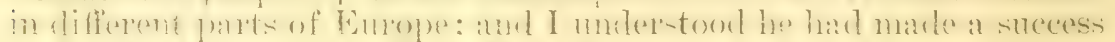
of it. They atled him (om Meal Morpley: he is till alive: I know him.

Dr. Alsberg. The question is, whether we can fairly say he made a success of it, because the only countries where they ate corn meal 
before the war were comntries like Italy, Rommania. Buldaria crecese and the Levant. where they also produce it-inchuline southern Russiat. There was very little corn eaten in Great Britain on France. excepting in the form of ermetareh: or in the feandinarian countries. The hardent thing in the world to do is to ahange peoples"s food habits.

Senator Predan. You can mix the corn meal with something else and get them to eat it?

Dr. Alsmeng. Yes; that is the way they do it; which, of course, meets with the objection of the millers.

senator OwE. Dr. Pennington, you offer the sulstimlial objecetion that the firs on the Itlantie const. at lea-t. are on mioratory that they would not be arailable for any batking plants on a very larere scale throughout the year. Is that what I am to understand?

STATEIVENT OF DR. M. E. PENNINGTON, CHIEF OF FOOD RESEARCH LABORATORY, BUREAU OF CHEIISTRY, DEPARTNENT OF AGRICULTURE.

Di. Pexpington. No; I would not go quite as far as that. But

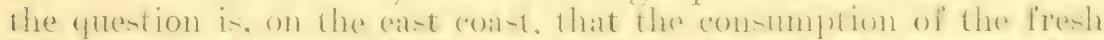
fish in competition with the amning plant or the drying plant is me which is a good deal more important than it is on the wert roast. where the camning industry hat haul rather the right of way in the past.

Of course, we have the Gloucester dried-fish industry, and salted

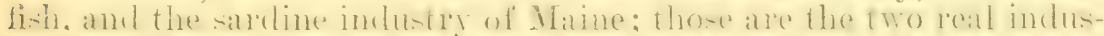
tries in the way of remdering fi-h induerishable on the eat soast aside from freezing. whith is of course, anom her method of preserving fish: and so far as they are hard frozen they are pradically imprerishable.

But we halde never had the derelopment of the amuing or the dry-

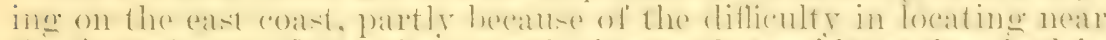
the factories the fish on be canned-just such trouble a- they hat in

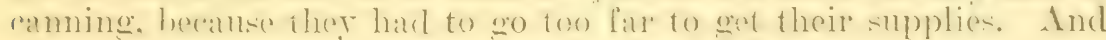
then there is the competition with the fresh fish.

Now, that is one thing that we may be able to do something with in Florida, where the sumply is heary ordinatily: it has heen pretty short this summer. Where we can have an all-the-year-round fishing husinew. where the winter wenther does not interfere with it, and

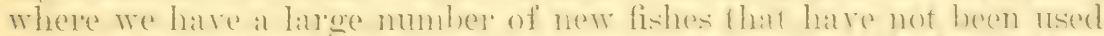
for ford heretofore-only beally used-and which ran be hambled in

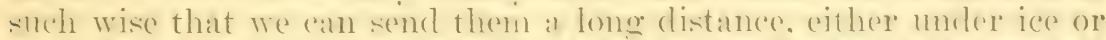
hard frozen, or when we know how ther can mudoulitedly be snoked or salted and canned, as on the Gulf coast, we may be able to do something. We have one cannery on the Gulf coast now. I tele-

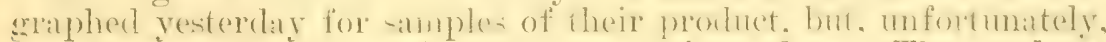
there has not been time for them to get it up here. The products that that monery is putting out are rery attractive in a great many ways. It is an entirely new industry down there.

Senator Owex. The test really has not been adequately made, as

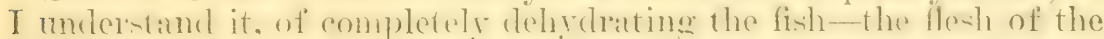
fish?

Dr. Punington. For food purposes?

Senator Owex. So as to reduce it to a powder, or to a dry meal? 
Dr. Pexpingrox. We have the fish meals, which are used for cattle feeds and poultry feeds, and for fertilizers.

Senator Owen. Yes.

Dr. Penningtox. It is not as fine as flour, but it is a fine meal.

Senator Owex. How is that done-just by subjecting it to heat?

Dr. Pexington. Ordinarily the oil is subtracted first. because in many cases the oil is the more valuable product.

Senator Owen. Yes.

Dr. Pexsmatox. Then the remaining material is dried by hot air and pressure.

Senator Oww. But for human food the fish has not been really put on the market as a dried meal, with the oil remaining in the fish?

Dr. Pennington. Not that I know of.

Dr. Coқвr. We have been making some experiments with the fresh fish, and we now have a product that looks satisfactory; but we are not sure as to its keeping qualities. It will take some time to test that out. Then there are problems as to flaror and texture.

Senator Owex. When the fis h lias been dehydrated, does the oil of the fish seem to be sufficient to act as a preservative?

Dr. Coner. The fish does seem to be rery well preserved. I am not enough of a chemist to know whether the oil would have much effect or not.

Dr. WeBEr. I think that is one of the points that will have to be given very careful attention to determine whether the oil will not become rancid when it is dried, and therefore spoil the product.

Senator Owen. Yes.

Dr. WEener. There are certain varieties of fish which will dry more quickly than others.

Senator Owrx. Yes; I understand, as a matter of fact, that the oils themselves undergo decomposition becanse of water heing left in the oil.

Dr. Weiber. Yes.

Senator Owrx. Ind if the extraction of the water is complete the oils are self-preservative.

Dr. WenEr. Well, the other factors there are light and temperature, which eanse ranciclity: if you remove the moisture entirely, you remore one of the causes of the oil spoiling. Now, a dried produet of fish might enntain 4 or 5 per cent of moisture. In fact, the commercial freds from fish do contain from 5 to 8 per cent of water. They are very dry, and will rattle around; still that might be sufficient water to cause rancidity in the oil.

Mr. Radchtre. Thile it is not part of this hearing. I may say that the Burean of Fisheries are conducting experiments now with regard to the dehydration of fish, and we are pushing that work as rapidly as we can to see what can be done in the dehydration of fish.

Senator OwEx. That experiment is being carried on by the Burean of Fisheries, is it?

Mr. RadCLIFFE. Yes.

Senator Owen. Where?

Mr. Ranctury. In New York City. A rery small plant has been assemblecl, and we are gradually making experiments to start the development of this thing. 
Senator Owex. Are you doing that by a racum system?

Mr. RadCLIfFe. Yes; a vacuum system.

Senator Owex. The adrantages of the vacuum system, as I understand it, are that, not using heat, the results are more reliable than where heat is used, as that may result in decomposition.

Mr. Radchfre. I'es. One of our initial experiments will go to the other extreme, the use of cold.

Senator Ower. The use of cold?

Mr. Radchiffe. Yes, sir. We freeze the fish and extract the moisture.

Senator Owex. Just as you would in the case of fruit juices?

Mr. Rancerfe. I am not familiar with the method emplover with fruit juices.

Senator Owex. Dr. Weber, will you explain the operations at Gloucester?

The Chairmax. The salting process.

Senator Owex. What you have done in the way of preserving with salt.

Dr. Weber. We have not been preserving with salt.

Senator Owex. What have you done at Gloucester?

Dr. WeBer. We have been interested in the canning and storage of fish and experiments on the process of improring the camning of dogfish. or gratrish. Tre have some simples of those here that I would like to show you.

Senator Orven. All right.

Mr. Mrener. And in dehydrating fish. Those were the three main features of the work we were proposing to do. When you mentioned a moment ago the method of drying in a vacmum it reminder me that we are installing a racmum apparatus for drying firh there. which had just arrived when I was called down here.

But the surprising thing is that fish can be dried to a very nice product, and a good-appearing product. hy simply driving a ir into these fumel pijes. such as the use in the drying of saldines: by cooling the fish previonsiy and dring it into a enmulatively dry condition it dries domn into a very nice product.

Senator Owex. The old-fashioned herring-I do not know how it is treated-hut I have always learded it as a very attrative dinh.

Dr. TVEBER. It is smoked-

Senator Owex (interposing). It is driol and smolied and sulled, is it not?

Dr. Weber. A rereat deal of water is taken from the fi-h previons to drying by the saltine. It is put down in salt hrine and held for a few days and then leept in the atmo-phere a fer dars mull it is thoroughly dried. The smoking also acts as a preservative.

Senator Owex. It looks to me as if rou would get the moisture back again.

Dr. Alsuerg. It does to some extent, but you ser they are partied in salt. and the salt being hyclroscopic removes the water and ilissolves itself.

Senator Owex. Yes; I guess that is right.

Mr. Mraser. The salt is for the purpose of axtrating the watel. The dried products came back dehyclrated in rery nice shape and form. 
I was talking about the use of oil in the fish a moment ago. Such fish as the whiting and the end will dry to much better adrantago than mackerel, for instance, which is a very fat fish and which you will not be able to dry at all; that is. the amomint of fat is rery much angmented in the dived product. They an be returned to their original condition by soaking in water-they will return very nicely to their original condition. The fiber is not ynite as soft as it is in the original fish. We are planning. before saring anything slefinitely about that to test out whether this dried product will lieep properly: whether or not. When it is put ipon the marlet, it will hecone lancid and mpleasant. The little experience we have had so firl als to that, particularly with dried roe-

Senator "Owex (interposing). The dried. salt herring seems to stand very well; that seems to have been very stable, and it has been very popular.

Dr. Wiswe. That has been rery popular: quantities of dried smoked herring are shipped to the southern climate.

Senator Owen. That would seem to have fairly tested out the drying and salting of fish, would it not?

Dr. Wreser. Well. the smoking adls a meservative to that and at the same time gives it a distinctive flaror:

Senator Owen. Yes; it gives it a distinctive flavor. I wanted to ask. Dr. Weber. What the rorermment, in rour jurloment. shomld do with regard to extending the experiments and providing the means necessary for developing them?

Dr. WeBER. I think there is more opportumity in the fishing industry-my experience is only on the Atlantic coast, however-of

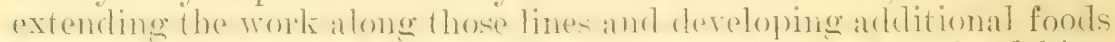
than with any othere forel product. It seems to me that the fishing industry has been less exploited than any other of similar importance.

Sienator ()wax. There hats heen reer little exploitation by the forernment of the fish industry of America, has there not?

Dr. Weber. Yes, that is true. There is one other thing I should like to say:

I have had a good many of the fish people ask for Federal inspection-this wat mosolicited on my part-but they have rather fert that they romld reach the desired quality in their product better if they had corermment inspection, particularly in regard to storage houser. The people who have been interested are people who would put their products into storage warehouses.

Senator Orras. Has your departnent heren furnisherl with all of the means you could profitably employ along this line?

Dr. Weber. As I say, I think we could expand to a very much greater degree than we are doing now.

Take Gloucester, for instance: There is every opportunity to do

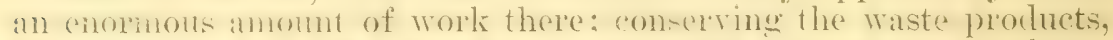
for instance, and eren insisting on malketing the waste products. The have sone products that we have developed from the use of fish which are not rearlily sold fresh, and in which their "anning products are limitert: and the eombination of these fish with a releal makes a good cereal loaf. 
The Gorton Pew Fish (Yo., which hats been reforted to, and with which we are cooperating. is getting ready to aldertise and leatures

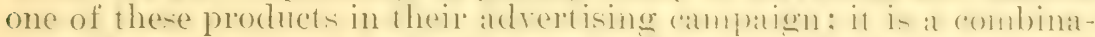
tion of a cereal, such as hominy ol hater. with whiting. making a loaf and camning it: and that will he put on the maldet this roming year.

The have also given some as istance to those same people in putting clam extract on the market. I have several samples of that liere which are rather tasty. That is, by the use of racuum drying or dehydration, extracting a great part of the water oul of the clam liquor when it comes from the steamer and evaporating it down to at paste, and then, by the addition of a small amount of that water, bringing it back.

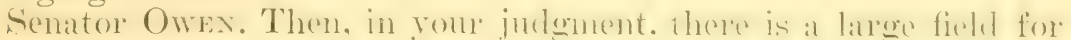
the development of food products, both for our markets and for export abroad?

Dr. Weber. Oh, yes. If this dehydration of fish proves satisfactory and we can derelop eren a few products from certain rarieties of fish. I think there will he a wondertul une for - 11 h a thine as that. It goes without saying that there will be advantages in shipping: in fact, in many ways there will be an arlvantage in the use of that product.

Senator Owex. I do not think Memhers of Comeresch have harl ninch opportunity of knowing what the opportunities are in the derelopment of values for food from fish. So many men live in the interior and never come in contact with the question, and there is no particular reason why they should have their attention called to it.

Dr. Alsmerg. Senator. I have always felt that if only small sums had been spent for the last 10 or 12 realis for the development of the fish inchustry, or this packing indu-try. it would have heen of immense benefit. Of course. the gue tion aries-it is only fair to say thatwhether that development shomlel be through the Department of Agriculture or through the Burean of Fisheries. I think we are all agreed that an experimental camnery and laboratory should be started both on the Atlantic and Pacific coasts under some one's control.

Senator Owex. I do not think that is of great importance. They seem to have been working happily together, wo fatr ats they have gone.

Dr. Alsberg. Very much so.

Dr. Wrener. I want to sily that our work there in these matters has been in direct cooperation with the Bureau of Fisheries.

Senator Owex. Then it comes right batck to ('ongrees to develop this matter adequately, in order to meet the increasing demands of the American people for food, and alo to ntilize the values which our fisheries really have if they are properly dereloped. Wo have had an enormons output of products in the United states throngh agriculture and through onr factories, and partly lrom on fisheries. but I am quite sure nothing like the way the fisheries conld be dereloped if it were given orderly attention.

Dr. WeBER. That is absolutely correct.

Dr. Clark. I will submit a list of pulblications by the Department of Agriculture relating to the snlject. (The lisi referred to was 
subsequently submitted by Dr. Clark and is here printed in full, as follows:)

List of bulletins and publications of the Burcau of Chemistry velating to fish and submitted herewith.

1. "Shrimp: Ifundling, Transportation, and Uses," l, E. 1). Clarls and Leslie MacNaughton. U. S. Department of Agriculture, Bulletin No. 538.

2. "A Chemical study of lood Frishes-The Analysis of 'Twenty Common Food Fishes with Especial Reference to a Seasonal Variation in Composition," by E. D. Clark and L. H. Almy. Published in Journal of Biological Chemistry, Volume XXXIII, p. 483.

3. "The Commercial Freezing and Storing of Fish," by L. L. Clark and L. H. Almy," U. S. Department of Agriculture, Bulletin No. 635.

4. "Analyses of 'Twenty Foor Fishes of the Facific Coast," by" L. D. Clark, E. M. Brown, and D. B. Dill. Unpublished data for a forthcoming bulletin.

5. "The Preservation of Sardines by Smoking," by E. D. Clark and H. D. Davi. Special bulletin to the fish trade.

6. "The Preparation of Kippered Shad," by E. D. Clark and H. D. Davi. Special bulletin to the fish trade.

7. " Kippering Barracuda, with Especial Reference to Canning," by E. D. Clark and H.D. Davi. Special bulletin to the fish trade.

8. "Supplementing Our Meat Supply with Fish," by M. E. Pennington, U. S. Department of Agriculture Year Book for 1913, p. 191.

9. "Shipping Fish Three Thousand Miles to Market," by E. D. Clark, U. S. Department of Agriculture Year Book for 1915, p. 155.

(Samples of fish and fish products were thereupon exhibited to the members of the subcommittee and the other Senators present.)

(Thereupon, at 12 o'clock noon, the subconmittees adjourned.) 



\section{Makers}

yracuse, N. V.

PMT. JAK. 21, 1928 
